\title{
HETEROSIS IN RELATION TO COMBINING ABILITY IN RESTORER LINES OF SUNFLOWER
}

\author{
Sawargaonkar, S.L. ${ }^{* 1}$ and Ghodke, M.K. ${ }^{2}$ \\ ${ }^{1}$ Marathwada Agricultural University, Parbhani, Maharashtra 431402, India \\ ${ }^{2}$ Oil Seed Research Station, Latur 413512 (M.S.), India
}

Received: March 10, 2008

Accepted: May 25, 2008

\section{SUMMARY}

In order to execute a breeding procedure efficiently, it becomes inevitable to examine the relationship between combining ability and heterosis. In the present investigation, diallel analysis of restorer lines ( $\mathrm{R}$ lines) and their restorer $\times$ restorer $(R \times R)$ crosses was employed to identify and develop elite ' $R$ ' lines for subsequent use in sunflower hybrid development programs. Crosses with high SCA effects were arranged in order of their per se performance, general combining ability of the parents of these crosses and per cent heterosis over standard check hybrid LSFH-35 and KBSH-1. Best GCA effects and high mean performance characters were observed between high $\times$ high, low $\times$ high or low $\times$ low general combiners. The combinations $\mathrm{J} / 6 \times \mathrm{NDR}-1$, $6 \mathrm{D}-1 \mathrm{R} \times$ DMLT-1Y, NDR-1 $\times$ LR-451 and $6 \mathrm{D}-1 \mathrm{R} \times$ DMLT-1Y, which were best for seed yield/plant, oil content and 100-seed weight and head diameter, respectively, were between high $\times$ high combining parents, indicating additive $\times$ additive effects are fixable components, and single plant selection would be desirable in their segregating generations. The combination NDR$856 \times 6 \mathrm{D}-1 \mathrm{R}$, with high per se performance for pollen productivity, was between low $\times$ high combining parents, and the combination 6D-1R $\times$ NDR-1, for plant height, was between low $\times$ low combining parents, indicating better complementation between favorable alleles of the involved parents.

Key words: heterosis, combining ability, sunflower restorer lines

\section{INTRODUCTION}

Information on heterosis in sunflower (Helianthus annuus L.) is essential for developing new hybrids. As data on this aspect are scant, an experiment was conducted to study the extent of heterosis in relation to combining ability effects for yield and other important characters of sunflower. The discovery of cytoplasmic

* Corresponding author: Phone 02452 ( 249644 );

e-mail: id-Shri_Breeder@ Rediffmail.com

This paper is a part of M.Sc. (Agri.) thesis submitted by first author to Marathwada Agricultural University, Parbhani. 
male sterility (Leclercq, 1969) and fertility restoration system (Kinman, 1970) is considered to be the milestone in the hybrid-breeding era of cultivated sunflower. The superiority of hybrids over open pollinated populations in terms of uniformity, autogamy, productivity, yield stability, oil content and tolerance to pest and diseases shifted the breeding emphasis from population improvement to heterosis breeding. Diallel analysis of restorer lines ( $R$ lines) and their restorer $\times$ restorer $(R$ $\times R$ ) crosses can help to identify and develop elite ' $R$ ' lines which later can be used in sunflower hybrid development programs. The analysis of combining ability of Griffing (1956 b), method II, model 1 was employed in the present investigation to get an overview of genetic architecture of yield and its components.

\section{MATERIALS AND METHODS}

The experimental material utilized in the present study comprised of 8 diverse restorer lines of sunflower, their $28 \mathrm{~F}_{1}$ 's and two checks. The crossing technique described by Putt (1941) was employed. In the first season, i.e., in Kharif 20062007, each genotype was sown in 2 rows. One row was kept for emasculation of flowers and their pollination. The other row was kept for collection of pollen grains in petri dishes and pollination was done in selected emasculated flower. For emasculation, unopened disc florets from 2-3 peripheral rows of head were selected and florets of the remaining rows were eliminated. Forceps were cleaned by dipping in ethyl alcohol. Hand emasculation was done prior to opening of flowers by removing the anther tube with forceps and bagging the head after that. Heads of male parents were simultaneously covered. On the next day, pollen collected in petri dish was dusted on the emasculated florets.

All these genotypes were crossed in half-diallel fashion without reciprocals. The complete set of experimental material comprised of 38 genotypes, i.e., 8 restorer lines ( $\mathrm{R}$ lines), 28 crosses and 2 checks, which were sown in a randomized block design with 3 replications in Rabi 2006-2007. The total plot size was $1.20 \times 4.5 \mathrm{~m}$. Recommended cultural practices were followed while raising the crop. Observations were recorded for days to 50 percent flowering, days to maturity, plant height $(\mathrm{cm})$, head diameter $(\mathrm{cm})$, pollen productivity per plant $(\mathrm{g})$, seed yield (g), 100-seed weight (g), filled seeds per head (\%), hull content (\%) and oil content (\%) of five plants per entry per replication. The analysis was carried out according to Griffing (1956) for diallel analysis. The hybrids LSFH-35 and KBSH-1 were used as standard checks for estimation of standard heterosis.

\section{RESULTS AND DISCUSSION}

Out of 28 crosses, only those showing high heterosis (compared with control), high specific combining ability (SCA) effects of the crosses and high general combin- 
ing ability (GCA) effects of the parents are reported in Table 1. The result shown in Table 1 revealed that the highest positive heterosis was observed in the cross 6D$1 \mathrm{R} \times$ DMLT-1Y for 100-seed weight (55.32\%) followed by the cross J/6 $\times$ NDR- 1 for seed yield per plant (43.98\%), NDR-856 $\times 6 \mathrm{D}-1 \mathrm{R}$ for pollen productivity $(34.85 \%)$, NDR-1 $\times$ LR-451 for head diameter (37.10\%) and 6D-1R $\times$ DMLT-1Y for oil content (14.68\%). A high heterosis in negative direction was observed in the case of the cross $6 \mathrm{D}-1 \mathrm{R} \times \mathrm{NDR}-1$ for plant height $(-24.68 \%)$. Similar findings for heterosis were recorded by Gangappa et al. (1997) who recorded high heterotic effects for head diameter, 100-seed weight, oil content and seed yield. Radhika et al. (2001) recorded high heterotic effects for head diameter and pollen productivity, Madhavi et al. (2005) and Moor et al. (2007) for seed yield/plant and Shankar (2007) for seed yield per plant and for oil content.

Table 1: Promising $\mathrm{F}_{1}(\mathrm{r} \times \mathrm{r})$ showing high per se performance, heterosis, their SCA effects and GCA status of their parents

\begin{tabular}{|c|c|c|c|c|c|c|c|c|}
\hline \multirow{2}{*}{ No. } & \multirow{2}{*}{ Hybrid } & \multirow{2}{*}{$\begin{array}{l}\text { Mean per se } \\
\text { performance } \\
\text { of hybrid }\end{array}$} & \multirow{2}{*}{$\begin{array}{l}\text { Standard } \\
\text { heterosis } \\
(\%)\end{array}$} & \multirow{2}{*}{$\begin{array}{l}\text { SCA } \\
\text { effect }\end{array}$} & \multicolumn{2}{|c|}{$\begin{array}{l}\text { GCA status } \\
\text { of parents }\end{array}$} & \multicolumn{2}{|c|}{$\begin{array}{l}\text { Mean performance } \\
\text { of parents }\end{array}$} \\
\hline & & & & & $\mathrm{P}_{1}$ & $\mathrm{P}_{2}$ & $\mathrm{P}_{1}$ & $\mathrm{P}_{2}$ \\
\hline \multicolumn{9}{|c|}{ Seed yield } \\
\hline 1 & $\mathrm{~J} / 6 \times \mathrm{NDR}-1$ & 43.67 & 43.98 & 11.75 & 9.73 & 0.59 & 22.67 & 15.67 \\
\hline 2 & $\mathrm{~J} / 6 \times \mathrm{MR}-1$ & 39.00 & 28.549 & 9.11 & 9.73 & -1.44 & 22.67 & 6.00 \\
\hline 3 & $\mathrm{~J} / 6 \times 6 \mathrm{D}-1 \mathrm{R}$ & 37.67 & 24.20 & 8.35 & 9.73 & -2.01 & 22.67 & 7.00 \\
\hline 4 & $\mathrm{~J} / 6 \times \mathrm{NDR}-856$ & 36.00 & 18.86 & 7.71 & 9.73 & -3.06 & 9.73 & 12.00 \\
\hline \multicolumn{9}{|c|}{ Oil content } \\
\hline 1 & $6 \mathrm{D}-1 \mathrm{R} \times \mathrm{DMLT}-1 \mathrm{Y}$ & 40.79 & 14.68 & 3.59 & 1.46 & 0.88 & 42.74 & 36.77 \\
\hline \multicolumn{9}{|c|}{ Head diameter } \\
\hline 1 & NDR-1 $\times$ LR-451 & 16.00 & 37.10 & 4.94 & 0.65 & 0.32 & 8.00 & 7.67 \\
\hline 2 & $\mathrm{~J} / 6 \times \mathrm{LR}-451$ & 15.00 & 28.53 & 2.77 & 1.82 & 0.32 & 11.67 & 7.67 \\
\hline \multicolumn{9}{|c|}{ 100-seed weight } \\
\hline 1 & $6 \mathrm{D}-1 \mathrm{R} \times \mathrm{DMLT}-1 \mathrm{Y}$ & 6.87 & 55.32 & 1.88 & 0.05 & 0.89 & 2.83 & 5.31 \\
\hline 2 & $\mathrm{~J} / 6 \times 6 \mathrm{D}-1 \mathrm{R}$ & 5.77 & 30.45 & 1.15 & 0.52 & 0.05 & 4.29 & 2.83 \\
\hline 3 & MR-1 $\times$ DMLT-1Y & 5.35 & 20.96 & 0.75 & -0.34 & 0.89 & 2.42 & 5.31 \\
\hline 4 & NDR-856 $\times$ NDR-1 & 5.35 & 20.96 & 1.93 & -0.41 & -0.21 & 1.55 & 2.24 \\
\hline \multicolumn{9}{|c|}{ Pollen productivity } \\
\hline 1 & NDR-856 $\times$ 6D-1R & 0.89 & 34.85 & 0.37 & -0.06 & 0.07 & 0.13 & 0.16 \\
\hline 2 & $\mathrm{~J} / 6 \times 6 \mathrm{D}-1 \mathrm{R}$ & 0.86 & 30.30 & 0.20 & -0.09 & 0.07 & 0.57 & 0.16 \\
\hline 3 & $M R-1 \times 6 D-1 R$ & 0.84 & 27.27 & 0.27 & -0.04 & 0.07 & 0.45 & 0.16 \\
\hline \multicolumn{9}{|c|}{ Plant height } \\
\hline 1 & $6 \mathrm{D}-1 \mathrm{R} \times \mathrm{NDR}-1$ & 116 & -24.68 & -20.43 & -7.37 & -3.87 & 120.67 & 127.67 \\
\hline 2 & MR-1 × NDR-1 & 127.33 & -17.32 & -17.87 & 1.40 & -3.87 & 131.00 & 127.67 \\
\hline 3 & DMLT-1Y $\times$ LR-451 & 140.00 & -9.10 & -5.40 & 1.33 & -3.60 & 133.33 & 119.33 \\
\hline
\end{tabular}

The parents J/6, DMLT-1Y, 6D-1R, NDR-1 and MR-1 had desirable GCA effects in the desirable direction, exhibiting best combining abilities for seed yield, oil content and other desirable traits (Table 1). Many workers (Radhika et al., 2001; 
Manivannam et al., 2005; Moor et al., 2007) reported good general combiners for yield per plant, plant height, head diameter and 100-seed weight in sunflower.

In order to execute the breeding procedure efficiently, it becomes inevitable to examine the relationship between combining ability and heterosis. Crosses with high SCA effects, arranged in order of their per se performance, general combining ability of their parents and percent heterosis over standard check hybrids LSFH-35 and KBSH-1, are presented in Table 1 . Table 1 shows that best GCA effects and high mean performance characters were observed between high $\times$ high, low $\times$ high or low $\times$ low general combiners. The combinations $\mathrm{J} / 6 \times$ NDR-1, $6 \mathrm{D}-1 \mathrm{R} \times$ DMLT$1 Y$, NDR-1 $\times$ LR-451 and 6D-1R $\times$ DMLT-1Y, which were best for seed yield per plant, oil content, 100- seed weight and head diameter, respectively, were combinations high $\times$ high parents, indicating that additive $\times$ additive effects are fixable components, and that single plant selection would be desirable in segregating generations.

The combinations NDR-856 $\times 6 \mathrm{D}-1 \mathrm{R}$ and $6 \mathrm{D}-1 \mathrm{R} \times \mathrm{NDR}-1$, the former with high per se performance (0.89) for pollen productivity and the latter for plant height, were between low $\times$ high and low $\times$ low combining parents, respectively, indicating good complementation between favorable alleles of the involved parents. An ideal combination to be exploited is one where high degree of SCA is present in addition to high GCA in both or at least in one parent. From this point of view, the crosses J/6 $\times$ NDR-1, J/6 $\times$ MR-1, J/6 $\times 6$ D-1R and J/6 $\times$ NDR-856 appear to be worth exploiting (Table 1) for seed yield. The present results are in agreement with findings of Limbhore et al. (1997) and Goksoy et al. (2000), who also reported having obtained crosses with high GCA effects from parents having either high $\times$ high, high $\times$ low or low $\times$ low GCA effects.

\section{CONCLUSION}

The crosses J/6 $\times$ NDR-1, 6D- $1 \mathrm{R} \times$ DMLT-1Y, NDR- $1 \times$ LR-451, NDR-856 $\times$ $6 \mathrm{D}-1 \mathrm{R}$ and MR-1 $\times$ NDR-1 exhibited high per se performance, high heterosis and high SCA in addition to high GCA in both or at least in one of the parents (Table 1). These $r \times r$ crosses may be used in breeding programs for the development of new ' $r$ ' lines which confer superior yield performance. It is also suggested that simple recurrent selection or biparental mating followed by reciprocal recurrent selection among the crosses having desirable yield components may be effective in genetic amelioration of the characters under study. The parent J/6 and DMLT-1Y were good combiners for seed yield along with yield-contributing characters like pollen productivity, 100-seed weight, head diameter and oil content, while 6D-1R was a good combiner for oil content, plant height and pollen productivity. The parent NDR-1 was a good general combiner for dwarfness, head diameter and seed yield. These parents can be used in synthetic breeding programs. The present investiga- 
tion helped to assess the extent of heterosis, combining ability of the parents and performance of their crosses.

\title{
REFERENCES
}

Gangappa, E., Channakrishnaiah, K.M., Ramesh, S. and Harini, M.S., 1997. Exploitation of heterosis in sunflower (Helianthus annuus L.). Cro. Res. 13(2): 339-348.

Goksoy, A.T., Turkee, A. and Turan, Z.M., 2000. Heterosis and combining ability in sunflower (Helianthus annuus L.). Indian J. Agric. Sci. 70(8): 525-529.

Griffing, B., 1956. A generalized treatment of use of diallel crosses in quantitative inheritance. Heredity 10: 31-50.

Kinman, M.L., 1970. New development in USDA and state experiment station sunflower breeding programs. Proc. Fourth Int. Sunflower Conference, Memphis, 10 181-183.

Leclercq, P., 1969. The sterile male cytoplasmic chezle tournesoil. Annales de I' Amelioration des plantes. 19: 99-106.

Limbore, A.R., Weginwar, D.G., Gite, B.D. and Ghorade, R.B., 1997. Combining ability in sunflower ( Helianthus annuus L.). J. Soil and Crops 7(1): 39-42.

Madhavi, K.L., Vishnuvardhan, R. and Devasenamma, V., 2005. Hybrid vigour and combining ability in sunflower (Helianthus annuus L.) hybrids involving $\mathrm{cms}$ lines. J. Oilseeds Res. 22(2) 309-312.

Manivannan, N., Vidhyavathi, P. and Murlidharan, V., 2005. Diallel analysis in sunflower. Indian J. Agric. Res. 39(4): 281-285.

Moor, M.K., Raghavendra, H.R., Ratnaparkhi, R.D. and Rathod, P.K., 2007. Hybrid vigour and combining ability studies in sunflower. ISOR National Seminor 118-120.

Radhika, P., Jagadeshwar, K. and Khan, H.A., 2001. Heterosis and combining ability through line $\times$ tester analysis in sunflower (Helianthus annuus L.). J. Res. ANGRAU, 29(2-3): $35-43$.

Shankar, I.G., 2007. Heterosis studies on few diversified $\mathrm{cms}$ lines in sunflower (Helianthus annuus L.). ISOR National Seminar 97-99.

\section{HETEROSIS EN RELACIÓN CON APTITUD COMBINATORIA EN LÍNEAS RESTAURADORAS DE GIRASOL}

\author{
RESUMEN
}

La ejecución de procedimientos de mejoramiento eficientes hace inevitable examinar la relación entre aptitud combinatoria y heterosis. En la presente investigación, el análisis dialélico de líneas restauradoras (líneas R) y sus cruzamientos restauradora $\times$ restauradora $(\mathrm{R} \times \mathrm{R})$ puede ayudar a identificar $\mathrm{y}$ desarrollar líneas "R" elites, que pueden utilizarse más tarde en programas de desarrollo de híbridos de girasol. Los cruzamientos con altos efectos de SCA se ordenaron de acuerdo a su comportamiento per se, aptitud combinatoria general de los padres de dichos cruzamientos y heterosis porcentual sobre los híbridos estándar testigos LSFH-35 y KBSH-1. Se observó que las mejores combinaciones específicas, con alto comportamiento medio para los caracteres estudiados, provenían de cruzamientos de líneas con aptitud combinatoria general alta $\times$ alta, baja $\times$ alta o baja $\times$ baja. Las combinaciones $\mathrm{J} / 6 \times \mathrm{NDR}-1$, $6 \mathrm{D}-1 \mathrm{R} \times$ DMLT-1Y, NDR-1 $\times$ LR-451 y 6D-1R $\times$ DMLT-1Y, que fueron las mejores para rendimiento de semilla por planta, contenido de aceite y peso de 100 semillas y diámetro de capítulo, respectivamente, fueron entre padres de aptitud combinatoria general alta $\times$ alta, indicando que los efectos aditivos $\times$ aditivos son componentes capaces de ser fijados y que la selección por planta individual sería deseable en generaciones segregantes. Las combinación específica NDR-856 $\times 6 \mathrm{D}-1 \mathrm{R}(0,89)$, con alto comportamiento per se para produc- 
tividad de polen proviene del cruzamiento de padres de aptitud combinatoria baja $\times$ alta, mientras que $6 \mathrm{D}-1 \mathrm{R} \times \mathrm{NDR}-1$, de alta estatura, fue entre padres de aptitud combinatoria baja $\times$ baja, indicando una mejor complementación entre alelos favorables de los parentales involucrados.

\title{
LA RELATION ENTRE L'HÉTÉROSIS ET L'APTITUDE À LA COMBINAISON DE LIGNÉES RESTAURATRICES DE FERTILITÉ EN TOURNESOL
}

\author{
RÉSUMÉ
}

Afin d'être efficace en sélection, il est devenu inévitable d'examiner les relations entre l'aptitude à la combinaison et l'hétérosis. Dans la présente étude, l'analyse Diallel des lignées restauratrices (lignées $\mathrm{R}$ ) et de leur croisements Restaureur $\times$ Restaureur $(\mathrm{R} \times \mathrm{R})$ peut aider à identifier et développer des lignées d'élite " $R$ " qui peuvent être plus tard utilisées pour un programme de développement d'hybrides de tournesol. Les croisements avec de grands effets ASC sont classés dans l'ordre de leur performance per se, en général l'aptitude à la combinaison des parents de ces croisements et le pourcentage d'heterosis par rapport aux témoins LSFH-35 et KBSH-1. Il a été observé que l'effet de l'AGC pour la meilleure combinaison spécifique avec de très bonne perfomances sur différents caractères a révélé qu'ils l'étaient entre fort $\times$ fort; faible $\times$ faible; faible $\times$ fort. Les combinaisons $\mathrm{J} / 6 \times$ NDR- 1 , $6 \mathrm{D}-1 \mathrm{R} \times \mathrm{DMLT}$ $1 Y$, NDR-1 $\times$ LR-451, 6D-1R $\times$ DMLT-1Y sont les meilleures respectivement pour le rendement grainier par plante, la teneur en huile, le poids de mille grains et le diamètre du capitule, celles-ci entre les combinaisons parentales fort $\times$ fort, ce qui indique que les effets additif $\times$ additif sont des composantes qui peuvent être fixées, la sélection plante à plante sera intéressante dans des générations en ségrégations. La combinaison spécifique NDR-856 $\times 6 \mathrm{D}-1 \mathrm{R}$ (0.89) avec une forte productivité de pollen per se était entre une combinaison faible $\times$ fort, et $6 \mathrm{D}-1 \mathrm{R} \times \mathrm{NDR}-1$ pour la hauteur de plant entre faible $\times$ faible combinaisons parentales, ceci indiquant une complémentarité favorable entre allèles pour les parents impliqués. 